\title{
THE TWENTIETH ANNIVERSARY OF THE JOURNAL: EDITOR'S INTRODUCTION
}

\author{
Editor-in-Chief Edmundas Kazimieras ZAVADSKAS, \\ Managing Editor Jonas ŠAPARAUSKAS \\ Vilnius Gediminas Technical University, Sauletekio al. 11, Vilnius, Lithuania
}

This year, the Journal “Technological and Economic Development of Economy" is commemorating a significant milestone - its $20^{\text {th }}$ anniversary.

The serial issue of publications under a common title "Technological and Economic Development of Economy" was initiated in 1994. That year saw eight issues, followed by two issues in 1995, three issues in 1996, one issue in 1997 and one issue in 1998. Since 2000, the format of the publication changed and since 2003, the standard was one volume per year (four issues).

Journal "Technological and Economic Development of Economy" (TEDE) is a peer-reviewed quarterly journal that provides an international forum for the dissemination of the latest original research, achievements and developments in many areas of Economics, Economic Forecasting, Economic Development, Finance, Business \& Industry and Environmental Economics.

The Journal aims to provide a forum for researches in different fields of economics. Papers published in the Journal "Technological and Economic Development of Economy" are original articles presenting new information and reviews. These publications provide essential ideas and information that help new scientific inquiries and improve competency, efficiency and productivity in world markets.

In 1994-2007, the Journal published papers in Lithuanian, English, German and Russian. During the period, the journal was already referred by EBSCO, IRB Direct (ICONDA), SCOPUS and CSA databases.

Since 2008, the Journal is published entirely in English, which ensures its wider dissemination. Previously published by Vilnius Gediminas Technical University and the Lithuanian Academy of Sciences, the Journal cooperates with universities representing the Baltic Region: Riga Technical University (Latvia), Tallinn University of Technology (Estonia) and Lithuanian Operations Research Society. In the period 2008-2013, 24 issues of the Journal were produced containing 280 papers. 
In 2008, TEDE was indexed by Thomson Reuters Science Citation Index Expanded, Web of Science and the Impact Factor (IF) by the Thomson Reuter's Institute for Scientific Information (ISI) was provided in 2010 (IF = 5.685). Articles published in 2007 were indexed by the ISI Database.

In 2007-2014, there were 327 different publications published in TEDE: original articles - 310; editorials - 10; conference proceedings - 10; reviews - 6 ; and corrections - 1 .

The latest currently available Journal ranking is as follows: ISI Impact factor (2012) IF $=3.224$, 5-year Impact Factor $=1.972$, Immediacy Index $=0.237$, self-citation index 19 per cent; SCOPUS SCImago Journal Ranking (2012), SJR = 1.044; SCOPUS Source Normalized Impact per Paper (2012), SNIP $=1.284, \mathrm{H}_{\text {ind }}=23$.

The Journal is currently ranked in the $14^{\text {th }}$ position worldwide among 333 journals under the "Economics" category of the ISI Web of Science, based on values of Impact Factors (IF) published by the Thomson Reuter's Institute for Scientific Information (ISI) Web of Knowledge Journal Citation Reports. TEDE entered the first quartile (Q1) of its peer journals based on its worldwide impact under the "Economics" category of the ISI Web of Science. The Journal's IF is more than 4 times higher than the average IF (0.795) for this economics category.

Currently, the Journal TEDE is also referred by following databases: IndexCopernicus; C.E.E.O.L (Central and Eastern European Online Library); Gale ${ }^{\oplus}$ Academic OneFile, IntoTrac Custom); ProQuest: Ulrich's, Summon ${ }^{\mathrm{Tw}}$ ).

Since 2011, the Journal is co-published by Vilnius Gediminas Technical University (VGTU) Press and Taylor \& Francis. The design of the Journal was changed, electronic peer review and publishing platforms were launched, the number of submissions as well as internationalization of authors and reviewers increased, and the Journal's visibility expanded in the international academic community.

In the period 2007-2013, 28 Journal numbers and one supplement (in 2013) were produced containing 327 papers. Journal's international visibility and its impact on the scientific community has increased. Resumed information about the internationalization of the Journal suggests that although the Journal "Technological and Economic Development of Economy" was published in four languages since 2008, it contained 70 per cent of publications authored by Lithuanian scholars and only 26 per cent of publications by foreign authors and 4 per cent of joint manuscripts. 7 years of abstracting in WoS database resulted in 18 per cent of papers authored by Lithuanian scholars, 74.5 per cent - foreign authors and 7.5 per cent - joined papers in 2013.

In the beginning of 2014, a survey was made in order to determine the further development of volume of assignments to Lithuanian and foreign institutions in the period 2007-2013, i.e. since TEDE has become indexed by WoS database. In 2007-2013, there were assignments to 44 different countries in Authors affiliations in published papers in the Journal: Lithuania, Poland, China, Latvia, Iran, Taiwan, Turkey, England, Serbia, Slovenia, USA, South Korea, Czech Republic, Belgium, Portugal, Romania, Australia, Canada, Croatia, Ireland, South Africa, Algeria, Belarus, Chile, Estonia, Germany, Malaysia, Singapore, Slovakia, Azerbaijan, Brazil, Denmark, France, Greece, Israel, Italy, Kazakhstan, Thailand, Venezuela, Vietnam and Wales.

Information on the distribution of papers by continent in 2007-2013 is as follows: $74.4 \%$ of papers were from Europe, 20.0\% - Asia, 3.4\% - North and South America, 1.4\% - Africa, $0.8 \%$ - Australia. 
The Editors are pleased that the Journal "Technological and Economic Development of Economy" is becoming better known, popular and appreciated not only in Lithuania, but also in other countries. The number of published as well as received papers of high scientific quality is growing rapidly, the internationality and global dispersion of the Journal are visibly increasing.

We are thankful to our editorial staff who has been contributing to the success of the Journal. Research-active and reputable scholars help to ensure the scientific quality of the Journal: Professor Zenonas Turskis (Lithuania), Professor Galina Merkuryeva (Latvia) and Professor Roode Liias (Estonia).

We are proud of Journal's numerous and respectable Editorial Board. TEDE Editorial Board consists of 53 members, including 20 Lithuanian scientists and 33 (62 per cent) meritorious scientists from other European countries (Latvia, Estonia, Poland, Germany, Belgium, Croatia, Czech Republic, Ukraine, Spain, Turkey, Serbia, Romania and Portugal) and other countries of the world (USA, Israel, Taiwan and P. R. China).

Many members of the Editorial Board of the Journal TEDE are experienced publishers or Guest Editors of other Journals. We have to mention Prof. Hojjat Adeli, Willem K. M. Brauers, Donatas Čygas, Florin Gheorghe Filip, Cengiz Kahraman, Romualdas Ginevicius, Kosta Josifidis, Igor Kabashkin, Arturas Kaklauskas, Gang Kou, Binshan Lin, Jan W. Owsinski, Gheorghe Ruxanda, Yong Shi, Marinko Skare, Miroslaw J. Skibniewski, Roman Slowinski, Vytautas Snieška, Jelena Stankeviciene, Gražina Startiene, Dalia Štreimikiene, Tadeusz Trzaskalik, Gwo-Hshiung Tzeng, Serhiy Yerokhin. Their contributions help us improve the quality of the Journal.

It should be noted that a very large number of scientists contribute to the effective peer review process. In 2012-2013, papers were reviewed by over 245 reviewers, 10 per cent of them were Lithuanian scientists and the rest 90 per cent were reputed scientist from other countries of the world. The Editors of the Journal would like to express their sincere appreciation to all experts for their contribution to the quality of papers.

Finally, the Editors once again would like to express their genuine gratitude for all those who have contributed to the success of the Journal, its quality and significance in the academic world.

We are thankful to our publishers, i.e. to Vilnius Gediminas Technical University for supporting and funding the production of the Journal; to VGTU Press - for intense daily work related to the publishing of issues; to Taylor \& Francis as a reputed publisher - for following good business practice and influencing the quality and wide dissemination of the Journal.

We are grateful to members of the Editorial Board for many years of cooperation and contribution in ensuring the quality of the Journal.

Thanks goes to a large number of Reviewers for provided valuable comments and suggestions on the quality of submissions.

Special thanks goes to Contributors for selecting "Technological and Economic Development of Economy" to publish their research findings.

We would like to express our sincere gratitude to you all. We look forward to our further successful scientific cooperation. 